\title{
PENGENALAN NARKOBA PADA ANAK USIA DINI MELALUI PENDEKATAN METODE BERCERITA
}

\author{
RAIHANA $^{\mathbf{1}}$, SITI NURHAYATI ${ }^{2}$, AJRIAH MUAZIMAH ${ }^{\mathbf{3}}$ \\ Pendidikan Islam Anak Usia Dini Fakultas Agama Islam Universitas Islam Riau \\ 1raihana@fis.uir.ac.id \\ ${ }^{2}$ nurhayati912@gmail.com \\ 3 ajriahmuazimah08@gmail.com
}

\begin{abstract}
Underage drug users show very large numbers, so understanding the dangers of drugs needs to be planted as early as possible. Supervision is not only done by parents at home, but also by teachers and the surrounding community. Through the method of telling children, it is expected to be able to distinguish good deeds and bad deeds so that they can be applied in daily life. The method of telling stories using illustrated storybooks that are packaged in an interesting way can be of particular concern to children. The adverse effects of drug use, for children not only will lose their future but will also lose their identity as young people who are creative and innovative, using drugs means children damage themselves, because as we all know that drug use will continually damage the nervous system the brain that will be felt throughout his life, even if the person has stopped using drugs. The method of telling stories by conveying information and knowledge to early childhood about the adverse effects of drug use is fun and will be stored in memory until adulthood so that the hopes and desires to make the younger generation will avoid drugs will be realized.
\end{abstract}

Keywords: Introduction, Narcotics, Early Childhood, Storytelling Method

\section{PENDAHULUAN}

Narkoba sudah mulai merambah ke belahan dunia khususnya Indonesia. Bahkan dari kalangan anak-anak, pemuda atau remaja sendiri telah menjadi korban zat adiktif ini. Dengan meningkatnya keprihatinan dan kepedulian masyarakat terhadap masalah penyalahgunaan narkotika, masyarakat mengharapkan adanya perhatian dan tindakan nyata dan tegas.
Menurut Undang-Undang RI Nomor 35 Tahun 2009, tentang narkotika pada Bab I Pasal I, narkotika adalah zat atau obat yang berasal dari tanaman atau bukan tanaman, baik sintetis maupun semi sintetis, yang dapat menyebabkan penurunan atau perubahan kesadaran, hilangnya rasa nyeri dan dapat menimbulkan ketergantungan. Kata "Narkotika" sendiri berasal dari Bahasa Yunani "Narkoum" yang berarti membuat 


\section{GENERASI EMAS}

Jurnal Pendidikan Islam Anak Usia Dini

Vol. 01 No. 02, Oktober 2018

lumpuh atau membuat mati rasa. Namun perlu diketahui sebelumnya bahwa narkotika memiliki khasiat dan manfaat yang digunakan dalam kedokteran dalam penanganan kesehatan dan pengobatan, serta berguna bagi penelitian perkembangan ilmu pengetahuan farmasi/farmakologi. Ironisnya saat ini malah disalahgunakan oleh pihak tertentu yang menjadikan narkotika sebagai komoditas ilegal. Dampak narkoba, jika disalahgunakan, seperti halnya singkatan kata tersebut memang sangatlah berbahaya bagi manusia (Cahyantoro, 2016).

Berdasarkan data Badan Narkotika Nasional (BNN) (dalam Setiawan), kasus pemakaian narkoba oleh pelaku dengan tingkat pendidikan SD hingga Tahun 2014 berjumlah 112.305. Data ini begitu mengkhawatirkan karena seiring dengan meningkatnya kasus narkoba (khususnya dikalangan usia muda dan anak-anak, penyebaran HIV/AIDS semakin meningkat dan mengancam). Penyebaran narkoba menjadi makin mudah karena anak SD juga sudah mulai mencoba-coba menghisap rokok. Tidak jarang para pengedar narkoba menyusup zat-zat adiktif (zat yang menimbulkan efek kecanduan) ke dalam lintingan tembakaunya.
Data di atas, menyatakan bahwa pemakai narkoba yang berusia di bawah umur menunjukkan angka yang sangat besar, maka dari itu pemahaman tentang bahaya narkoba perlu ditanamkan sedini mungkin. Melalui pendidikan untuk Anak Usia Dini tenaga pendidik dapat memberi pemahaman melalui beberapa strategi pembelajaran untuk menyampaikan kegiatan belajar mengajar, diantaranya dengan metode bercerita dengan menggunakan media buku bergambar agar anak merasa tertarik sehingga akan lebih mudah tertanam di alam bawah sadar anak.

Berdasarkan pemaparan di atas, penulis tertarik untuk memberikan pemahaman kepada anak-anak usia dini sebagai cikal bakal generasi muda yang akan membangun bangsa Indonesia kedepannya tentang bahaya dan dampak buruk penggunaan narkoba melalui metode bercerita dengan menggunakan media buku bergambar.

\section{PEMBAHASAN}

Narkoba (narkotika, psikotropika dan bahan adiktif berbahaya lainnya) adalah bahan atau zat yang jika dimasukan dalam tubuh manusia, baik secara diminum (oral), dihirup, maupun disuntikkan yang dapat mengubah pikiran, suasana hati atau 


\section{GENERASI EMAS}

Jurnal Pendidikan Islam Anak Usia Dini

Vol. 01 No. 02, Oktober 2018

perasaan, dan perilaku seseorang. Narkotika adalah zat atau obat yang berasal dari tanaman atau bukan tanaman, baik sintetis maupun semi sintetis yang dapat menyebabkan penurunan atau perubahan kesadaran, hilangnya rasa nyeri dan dapat menimbulkan ketergantungan (UndangUndang No. 22 Tahun 1997).

Narkoba yang kini banyak disalahgunakan dalam fungsinya memiliki dampak yang buruk pada tubuh manusia. Obat - obatan yang disalahgunakan pemakaiannya dan masuk ke dalam tubuh akan mempengaruhi tubuh terutama sistem syaraf pusat. Terutama aktivitas mental emosional dan perilaku, disebut dengan zat psikoaktif. Efek yang ditimbulkan oleh zat psikoaktif dapat menurunkan kewaspadaan dan penampilan kognitif, seperti persepsi dan memori; efek menenangkan; efek menidurkan (Tina Afiatin, 2007).

Pengenalan materi narkoba pada anak-anak juga dimulai dari pemahaman yang sederhana. Kegiatan terarah, terstruktur dan berkesinambungan akan menghindari anak dari waktu kosong. Meminimalkan waktu kosong juga akan meminimalkan anak pada kegiatan yang tidak terarah. Selain itu, latihan yang terjadwal membuat orang tua dapat melakukan pengawasan pada seluruh kegiatan anaknya. Pengawasan tidak hanya dilakukan oleh orang tua di rumah tetapi guru dan masyarakat di sekitarnya.

Sekarang ini penyalahgunaan narkoba sudah masuk ke segala lini kehidupan kita, para pengedar narkotika tidak kekurangan akal dalam mencari korbannya melalui berbagai cara untuk mempengaruhi anakanak, dengan memberikan sesuatu yang digemarinya misalnya "permen, pulpen dan sebagainya". Orang tidak akan tahu bahwa di dalam permen atau pulpen tersebut terdapat zat-zat adiktif yang sangat membahayakan bagi anak.

Semakin tinggi tingkat pengetahuan masyarakat pada narkoba terutama informasi dampak negatif yang ditimbulkan, maka akan mempermudah untuk menjauhkan diri dari narkoba. Namun, pengawasan terpadu atas kerjasama orang tua, guru dan masyarakat sekitar tetap ada. Sehingga pengenalan dan penggunaan narkoba dapat diatasi sedini mungkin, terutama dikalangan anak usia dini. Karena anak usia dini menjadi sasaran yang paling mudah untuk menjadikannya sebagai korban narkoba, melalui iming-iming makanan ringan atau minuman. Dengan demikian, sangat diperlukan pengenalan materi tentang bahaya narkoba pada anakanak sejak usia dini oleh semua pihak. 


\section{GENERASI EMAS}

Jurnal Pendidikan Islam Anak Usia Dini

Vol. 01 No. 02, Oktober 2018

Usia dini adalah usia yang sangat menentukan dalam pembentukan karakter dan kepribadian anak. Menurut Augusta (2012) "Anak usia dini adalah anak yang berusia antara 3-6 tahun”. Menurut Cahya Maulidiyah (2014) "Pengertian anak usia dini ditujukan kepada anak yang berusia 0-6 tahun, seperti dalam Undang-Undang Republik Indonesia Nomor 20 Tahun 2003 tentang Sistem Pendidikan Nasional pada Pasal 1 Ayat 14 yang menyatakan pendidikan anak usia dini adalah pendidikan yang diperuntukkan bagi anak sejak lahir sampai usia 6 tahun".

Sedangkan, menurut Supartini (2004) mengungkapkan bahwa anak prasekolah adalah anak yang berusia 3 sampai 6 tahun dan mempunyai berbagai macam potensi. Potensi-potensi itu dirangsang dan dikembangkan agar pribadi anak tesebut berkembang secara optimal. Kemudian, jika ditinjau dari sisi usia kronologisnya, menurut kesepakatan UNESCO anak usia dini merupakan kelompok anak yang berada pada rentang usia 0-8 tahun.

Menurut Siti Aisyah, dkk., (2007) mengatakan bahwa anak usia dini memiliki karakteristik yang khas, baik secara fisik, psikis, sosial, moral dan sebagainya. Masa anak juga masa yang paling penting untuk sepanjang usia hidupnya. Sebab masa anak adalah masa pembentukan pondasi dan dasar kepribadian yang akan menentukan pengalaman anak selanjutnya. Pengalaman yang dialami anak pada usia dini akan berpengaruh kuat terhadap kehidupan selanjutnya. Pengalaman tersebut akan bertahan lama, bahkan tidak dapat terhapuskan kalaupun bisa hanya tertutupi.

\section{Metode Bercerita}

Metode digunakan sebagai suatu cara dalam menyampaikan suatu pesan atau materi pelajaran kepada anak didik. Metode yang diterapkan oleh guru baru berhasil, jika mampu dipergunakan untuk mencapai tujuan. Metode bercerita merupakan salah satu metode yang banyak digunakan di Taman Kanak-kanak. Sebagai suatu metode, bercerita mengundang perhatian anak terhadap pendidik sesuai dengan tema pembelajaran. Bila isi cerita dikaitkan dengan dunia kehidupan anak di TK, maka lebih mudah dalam memahami isi cerita tersebut. Anak-anak akan mendengarkan dengan penuh perhatian serta dengan mudah dapat menangkap isi cerita (Moeslichatoen R, 2004:157). Sementara itu, menurut Bahtiar (dalam Bachri, 2005) bercerita adalah menuturkan sesuatu yang mengisahkan 


\section{GENERASI EMAS}

Jurnal Pendidikan Islam Anak Usia Dini

Vol. 01 No. 02, Oktober 2018

tentang perbuatan atau sesuatu kejadian dan disampaikan secara lisan dengan tujuan membagikan pengalaman dan pengetahuan kepada orang lain.

Metode bercerita adalah suatu metode yang mempunyai daya tarik yang menyentuh perasaan anak. Islam menyadari sifat alamiah manusia untuk menyenangi cerita yang pengaruhnya besar terhadap perasaan. Oleh karenanya, dijadikan sebagai salah satu teknik pendidikan (Abudin Nata, 2001:97) pada anak usia dini.

Tujuan metode bercerita adalah agar anak dapat membedakan perbuatan yang baik dan buruk sehingga dapat diaplikasikan dalam kehidupan sehari-hari. Dengan bercerita guru dapat menanamkan nilai-nilai Islam pada anak didik, memberikan pemahaman mendalam ajaran agama dan bagaimana mengimplementasikan dalam kehidupan sehari-hari (Wahyuni, 2018:56), seperti menunjukkan perbedaan perbuatan baik dan buruk serta ganjaran dari setiap perbuatan. Melalui metode bercerita anak diharapkan dapat membedakan perbuatan yang baik dan perbuatan yang buruk sehingga dapat diaplikasikan dalam kehidupan seharihari.

Bercerita bukan hanya berfungsi sebagai hiburan tetapi juga merupakan suatu cara yang dapat digunakan dalam mencapai sasaran-sasaran atau target pendidikan. Metode cerita dapat menjadikan suasana belajar menyenangkan dan menggembirakan dengan penuh dorongan dan motivasi sehingga pelajaran atau materi pendidikan itu dapat dengan mudah diberikan. Fungsi metode bercerita adalah (1) menanamkan nilai-nilai pendidikan yang baik, (2) dapat mengembangkan imajinasi anak, (3) membangkitkan rasa ingin tahu, dan (4) memahami konsep ajaran Islam secara emosional (Novi Romawati, 2007:21).

Teknik bercerita dapat dilakukan dengan menggunakan alat peraga langsung, seperti gambar-gambar, benda-benda, media massa dan buku cerita bergambar. Teknik bercerita juga dapat dilakukan tanpa menggunakan alat peraga, misalnya hanya menggunakan jari tangan, mimik wajah atau ekspresi, dan suara-suara yang menirukan subyek cerita.

Kelebihan metode bercerita adalah kisah dapat mengaktifkan dan membangkitkan semangat anak didik, mengarahkan semua emosi sehingga menyatu pada satu kesimpulan yang terjadi pada akhir cerita, kisah selalu memikat, karena mengundang untuk mengikuti peristiwanya dan merenungkan maknanya, 


\section{GENERASI EMAS}

Jurnal Pendidikan Islam Anak Usia Dini

Vol. 01 No. 02, Oktober 2018

dan dapat mempengaruhi emosi seperti takut, perasaan diawasi, rela, senang, sungkan, atau benci sehingga bergelora dalam lipatan cerita (Armai Arief, 2002:159-162). Adapun kekurangan metode bercerita adalah pemahaman anak didik akan menjadi sulit ketika kisah itu telah terakumulasi oleh masalah yang lain, bersifat monolog dan dapat menjenuhkan anak didik serta sering terjadi ketidakselarasan isi cerita dengan konteks yang dimaksud sehingga pencapaian tujuan sulit diwujudkan (Novi Romawati, 2007:28).

\section{Pengenalan Narkoba pada Anak Usia Dini melalui Pendekatan Metode Bercerita}

Di Taman Kanak-kanak bercerita adalah salah satu metode yang dapat mengembangkan perkembangan bahasa anak. Sedangkan metode bercerita adalah cara penyampaian atau penyajian materi pembelajaran secara lisan dalam bentuk cerita. Perkembangan sosial dapat dikatakan sebagai pencapaian kematangan dalam hubungan sosial (Susanto, dalam Mashar, 2011).

Media berfungsi sebagai pembawa pesan kepada siswa dalam proses pembelajaran. Tidak terkecuali media buku cerita bergambar yang banyak digunakan untuk menyampaikan pesan dari isi buku kepada anak usia dini. Karena memang hakekatnya anak usia dini merupakan penerima pasif dari tekanan lingkungan.

Salah satu cara untuk meningkatkan kemampuan bercerita anak, yaitu dengan memberikan buku-buku bergambar. Karena buku bergambar mempunyai efek visualisasi yang dapat merangsang mata untuk menikmati gambar dan memahami teks yang memberi penjelasan pada gambar. Buku cerita bergambar termasuk salah satu media visual. Karena buku cerita bergambar yang dikemas secara menarik dapat menjadi perhatian tersendiri bagi anak dan memotivasi anak untuk semangat mengikuti pelajaran

Melalui metode bercerita menggunakan buku cerita bergambar anak akan tertarik untuk menyimak dan sangat digemari anak-anak, sekalipun ketertarikan awal cerita dimulai dari banyaknya gambargambar di buku, bukan tentang isi buku. Namun lambat laun anak akan mulai mendengarkan isi dari gambar yang disampaikan melalui bercerita yang dilakukan oleh orang dewasa di sekitarnya, apalagi jika metode yang digunakan ditunjang dengan penggunaan bahasa yang sederhana dan mudah dipahami anak-anak 


\section{GENERASI EMAS}

Jurnal Pendidikan Islam Anak Usia Dini

Vol. 01 No. 02, Oktober 2018

sehingga anak lebih berpotensi dalam mengembangkan bahasa yang sifatnya ekspresif. Begitu juga ketika akan menanamkan nilai-nilai sosial, agama dan moral pada anak usia dini, jauh lebih efektif jika pesan tersebut disampaikan dengan cerita menggunakan buku cerita bergambar.

Metode bercerita menggunakan buku cerita bergambar yang dikemas secara menarik dapat menjadi perhatian tersendiri bagi anak. Pelan-pelan anak akan melatih daya serap dan daya tangkap yang lambat laun akan tersimpan di memorinya. Sigmund Freud, Bapak ilmu Psikoanalisia menyebutkan bahwa lima tahun pertama dalam kehidupan anak sejak lahir sangat menentukan perkembangan kepribadian pada umur selanjutnya.

Guru sebagai pendidik di sekolah memberikan informasi dan pengetahuan tentang segala hal dengan cara yang tepat khususnya dampak buruk penggunaan narkoba pada anak usia dini, maka untuk usia selanjutnya pada saat meneruskan pendidikan yang lebih tinggi anak sudah memiliki pengetahuan dan informasi yang cukup serta kokoh dalam pergaulan di lingkungannya.

Sementara itu, masa kanak-kanak adalah masa yang paling penting untuk sepanjang usia hidupnya. Sebab masa kanak- kanak adalah masa pembentukan pondasi dan dasar kepribadian yang akan menentukan pengalaman anak selanjutnya. Pengalaman yang dialami anak pada usia dini akan berpengaruh kuat terhadap kehidupan selanjutnya. Pengalaman tersebut akan bertahan lama, bahkan tidak dapat terhapuskan kalaupun bisa hanya tertutupi. Dalam hal ini untuk menghindari dampak buruk di rentang masa kehidupan anak selanjutnya, maka dari usia dini anak sudah diberikan informasi dan pengetahuan.

Begitu juga untuk menyampaikan dampak buruk penggunaan narkoba, bagi rentang usia anak selanjutnya. Anak tidak hanya akan kehilangan masa depan tetapi juga akan kehilangan jati dirinya sebagai generasi muda yang kreatif dan inovatif. Dampak buruk selanjutnya adalah dengan menggunakan narkoba berarti anak merusak dirinya sendiri, karena seperti kita ketahui bahwa penggunaan narkoba secara terus menerus akan merusak sistem syaraf otak yang akan dirasakan selama hidupnya, sekalipun yang bersangkutan sudah berhenti menggunakan narkoba.

Penanaman karakter dan iman harus digencarkan sedini mungkin, agar ke depannya anak menjadi pribadi yang cinta akan dirinya sendiri, keluarga, agama dan 


\section{GENERASI EMAS}

Jurnal Pendidikan Islam Anak Usia Dini

Vol. 01 No. 02, Oktober 2018

tanah airnya. Apabila iman dan karakter

sudah kokoh maka kejahatan-kejahatan dikalangan generasi muda dapat dientaskan, seperti kasus penyalahgunaan narkoba, tawuran antar pelajar, tindak kekerasan, dan kasus pencurian.

Metode bercerita menggunakan buku cerita bergambar yang dikemas secara menarik dapat menjadi perhatian tersendiri bagi anak apalagi jika metode yang digunakan ditunjang dengan penggunaan bahasa yang sederhana dan mudah dipahami anak-anak, sehingga anak lebih berpotensi dalam mengembangkan bahasa yang sifatnya ekspresif. Dalam metode bercerita melalui buku cerita bergambar dapat diceritakan apa saja, termasuk bercerita tentang penyalahgunaan narkoba tentunya disesuaikan cerita dan gambarnya dengan umur anak usia dini.

\section{PENUTUP}

Ada banyak dampak buruk penggunaan narkoba yang bisa disampaikan kepada anak melalui buku cerita bergambar diantaranya, anak tidak hanya akan kehilangan masa depan tetapi juga akan kehilangan jati dirinya sebagai generasi muda yang kreatif dan inovatif. Dampak buruk selanjutnya adalah dengan menggunakan narkoba berarti anak merusak dirinya sendiri, karena seperti kita ketahui bahwa penggunaan narkoba secara terus menerus akan merusak sistem syaraf otak, yang akan dirasakan selama hidupnya, sekalipun yang bersangkutan sudah berhenti menggunakan narkoba. Dengan telah rusaknya tubuh mereka maka anak akan sulit melakukan halhal yang berguna untuk kemajuan masa depan dan bangsanya. Sehingga tujuan untuk menjadikan anak generasi penerus harapan bangsa yang cinta akan tanah air sulit untuk diwujudkan.

Metode bercerita dengan menyampaikan informasi dan pengetahuan kepada anak usia dini tentang dampak buruk penggunaan narkoba secara menyenangkan dan akan tersimpan dalam memorinya sampai dewasa, sehingga harapan dan keinginan untuk menjadikan generasi muda akan terhindar dari narkoba akan terwujud.

\section{DAFTAR PUSTAKA}

Aisyah, Siti, dkk. 2008. Perkembangan dan Konsep Dasar Pengembangan Anak Usia Dini. Jakarta: Universitas Terbuka.

Arief, Armai. 2002. Pengantar Ilmu dan Metodologi Pendidikan. Jakarta: Ciputat Press. 


\section{GENERASI EMAS}

Jurnal Pendidikan Islam Anak Usia Dini

Vol. 01 No. 02, Oktober 2018

Augusta. 2012. Pengertian Anak Usia Dini. Diambil dari http://infoini.com/pengertian anak usia dini diakses tanggal 04 Juli 2018.

Bachri, B.S. 2005. Pengembangan Kegiatan Bercerita di Taman Kanak-Kanak dan Teknik dan Prosedurnya. Jakarta: Depdiknas.

Maulidiyah, Eka Cahya. 2014. Anak Usia Dini. Diambil dari http://ekacahyamaulidiyah.blogspot.co . .id/2014/02/anak-usia-dini_6.html

Maryanto, M, dkk. Membentuk Generasi Muda Berkarakter Tanpa Narkoba. http://media.neliti.com/media/publicati ons/168708.ID-membentuk-generasimuda-berkarakter-tanp.pdf

Moeslichatoen R. 2004. Metode Pengajaran Di Taman Kanak-kanak. Jakarta: Rieka Cipta

Mustaqila, S. Bahaya Narkoba. http://jurnal.arraniry.ac.id/index.php/d ustur/article/download/1190/889

Nata, Abuddin. 2001. Filsafat Pendidikan Islam. Jakarta: Logos Wacana Ilmu.
Romawati, Novi. 2007. Metode Bercerita sebagai Penanaman Pendidikan agama Islam pada Anak Usia Prasekolah di Taman Kanak-Kanak Bait Al-Falah Pondok Ranji. Skripsi. Jakarta: UIN Syarif Hidayatullah, Fakultas Ilmu Tarbiyah dan Keguruan.

Robilah. 2012. Upaya Meningkatkan Kemampuan Berbahasa Melalui Metode Bercerita dengan Buku Cerita Bergambar Pada Anak Kelompok B TK ABA Melika I Wedi Klaten Tahun Ajaran 2012/2013. Skripsi. Surakarta: FKIP UMS.

Setiyawan. Upaya Pencegahan Terhadap Penyebaran Narkoba. http://media.neliti.com/media/publi cations/170443-IDupayapencegahan-terhadappenyebaran-nar.pdf

Wahyuni, Ida Windi. 2018. Penerapan NilaiNilai Moral pada Santri TPQ AlKhumaier Pekanbaru. Generasi Emas Jurnal Pendidikan Islam Anak Usia Dini Volume 1 No. 1. Pekanbaru: UIR. 